Volume 9, No.5, September - October 2020

International Journal of Advanced Trends in Computer Science and Engineering

Available Online at http://www.warse.org/IJATCSE/static/pdf/file/ijatcse247952020.pdf

https://doi.org/10.30534/ijatcse/2020/247952020

\title{
The Electronic Educational Quiz Board Development to Test Student's Timing Diagram Knowledge of the Ladder Diagram in Programmable Logic Controller
}

\author{
Mohammad 'Afif Kasno ${ }^{1}$, Nik Muhammad Firdaus Zaimi ${ }^{1}$, Kamaru Adzha Kadiran ${ }^{2}$, Shahrizal Saat ${ }^{1}$, A. \\ F. Z. Abidin ${ }^{1}$, Mohammad Faisal Abdul Waduth ${ }^{3}$ \\ ${ }^{1}$ Faculty of Electrical \& Electronics Engineering Technology, Universiti Teknikal Malaysia Melaka, Malaysia, \\ mohammad.afif@utem.edu.my \\ ${ }^{2}$ Faculty of Electrical Engineering, Universiti Teknologi MARA, Malaysia \\ ${ }^{3}$ Faculty of Electrical Engineering, Universiti Selangor, Malaysia
}

\begin{abstract}
PLC educational quiz board or its acronym, PLC EQB, is a training package designed to test students ' comprehension of translating the timing diagram into an analogous ladder diagram. This is achieved by configuring the educational package to display questions about the mnemonic code. The student must configure an identical ladder diagram relation on the educational package. If the link has been made, the training kit will verify the consistency of the circuit. The purpose of this project is to get students interested in translating the timing diagram into the ladder diagram learning process. The project uses Arduino Mega, a commonly used microcontroller, to reduce the cost of the prototype. A survey is performed by students of the two Faculties of Engineering Technology at the Teknikal University of Malaysia Melaka. The results of the survey indicate positive feedback on the proposed educational package.
\end{abstract}

Key words : educational kit; electronic quiz board; educational quiz board; timing and ladder diagram; programmable logic controller.

\section{INTRODUCTION}

Programmable Logic Controller (PLC) is one of the commonly used Controller in industries. This due to its' high reliability and easiness to program. Thus, it is one of the controllers that had dedicated subject taught at tertiary level for most of the electrical-based engineering or technology subject. One of the commonly taught topics in PLC is the conversion of the timing diagram of a sequence-based operation into its ladder diagram equivalent. This project attempts to create an electronic quiz board to aid the process of testing students' knowledge on the topic matter. The aim of this project is to create the quiz board that is automatic which requires no supervision of the teaching personal when student operating it.

Based on the literatures done, there are many educational kits has been developed to help students learn and apply the knowledge with real engineering application. The kits usually will combine with hardware and software to implement the application and cover small sub-topics in the subjects.

As example, flowchart in learning $\mathrm{C}$ programming language is one of the most important concepts that students required to understand. M. R. Yaacob et. al [1] has proposed an educational kit to learn this concept using microcontroller. M. S. Karis et. al [2] has developed a hardware for Laplace Circuit Solver for the students to learn Laplace Transform Equation with Arduino Microcontroller. M. I. Z. M Zabidi [3] has developed a kit to understand the concept of mathematical transformation with practical hands-on. Learning to translate mnemonic codes in E-PLC has been developed by M. H. A. H. A. M. Faseh et. al [4].

Meanwhile, [5], [6], [7], [8], [9], [10], [11], [12] and [13] were the example of educational kits projects that implements hardware with Arduino microcontroller and other software such as android apps.

Other example educational kits that related to Control Systems includes learning transient response by applying water level by K. A Kadiran et. al [14] and applying DC motor speed controller with second order transient response by M. I. Z. M. Zakaria et. al [15]. The paper from Thanh-Nhan Huynh-Ly et. al [16] done the research on courses relationship to predict students' performance.

At a meta-level, the aim to develop the PLC EQB project is to attract the students' interest in learning PLC. It is observed that engineering students prefer spontaneous, pragmatic, and concrete style of learning [17]. Pragmatic shows that the students prefer practical hands-on and application in their learning style. Even studies like [18] and [19] shows the important of hands-on-learning. Having said that, it is a known fact that the hands-on activities are resource extensive [20]. Thus, the PLC EQB is seen practical where it is not only inexpensive, portable and function without any teaching personal's supervision.

This project has its limitation. The first limitation comes from the educational kit, itself. PLC EQB is only a proof of concept which being built to test the concept of having an automatic quiz board to test student knowledge on a specific topic in PLC. The word specific earlier suggests that the quiz board only covers the topic of conversion from ladder diagram 
to timing diagram which is a single topic in PLC. The number of questions is only limited to five questions. This is seen adequate to show the concept rather than to proof the effectiveness of the product. The second limitation comes from the methodology employed measuring feedback from the respondents. Rather than employing a complex quantitative methodology in designing the survey questions and analyzing the data obtained. This study keeps the question simple and the focus the functionality of the product rather than its effectiveness in improving students' marks.

The package has five questions which are presented in terms of the timing diagram. Students are then expected to create an equivalent ladder diagram relation on the educational package. If the connection is completed, the kit will automatically simulate the wiring connection of the ladder diagram made by the student and display the corresponding simulated timing diagram on the TFT LCD screen. Then, the quiz board compares the simulated timing diagram with the question timing diagram and provide the feedback to the student whether the student's ladder diagram connection is correct or wrong. This interactive element is believed to keep the student's interest and by doing so, the authors hope that the kit will be able to make students understand the translating timing diagram into equivalent ladder diagram.

\section{METHODOLOGY}

The PLC EQB consists of two parts, which are simulation and quiz. In the simulation section, students must first connect an equivalent ladder diagram so that they can see the output of the timing diagram. Whereas in the quiz part, the student should observe the question provided by the quiz board first before they configure the ladder diagram connection. The users must configure what will be the equivalent ladder diagram for the timing diagram in order to get a positive feedback from PLC EQB.

\subsection{Project Layout}

Figure 1 show the top view of the project layout which contains several important components for this project such as female header, 4x4 array keypad and thin-film-transistor of the liquid-crystal display (TFT LCD).

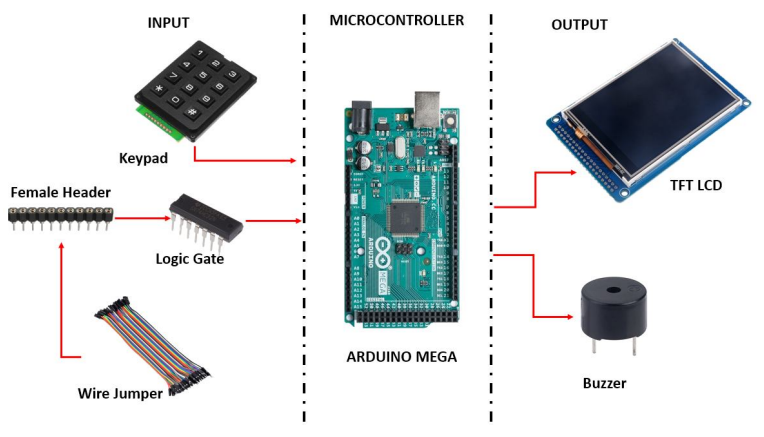

Figure 1: Project layout

\subsection{Block Diagram}

Figure 2 is a block diagram that shows the relationship between the components stated in Figure 1. The controller employed is Arduino Mega as this microcontroller provide more input output (I/O) pins. The inputs to Arduino Mega consist of a) 4X4 keypad; b) female headers; c) AND logic gate ICs; d) male-to-male jumpers. The $4 \times 4$ keypad is used to receive input related to the selection by user. The AND logic gate ICs is used to hold the current when reading the connection done by the user via the female header. The female headers and male-to-male jumper are used as connection apparatus for user to recreate the equivalent timing diagram on PLC EQB.

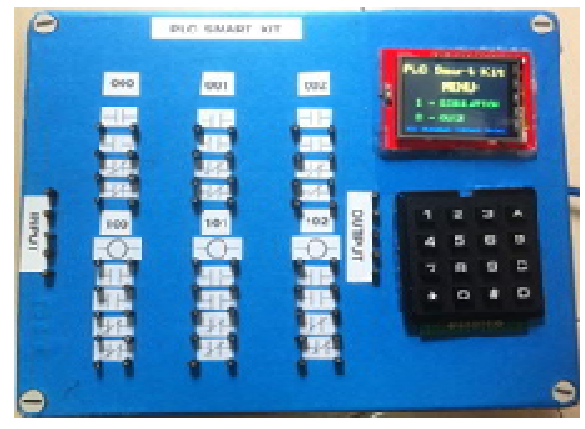

Figure 2: Project Block Diagram

\subsection{Connection Pins of Components on Arduino MEGA Board}

Instead of providing the schematic drawing of the product, this paper includes pin-to-pin connection of the product. This is deemed more suitable because it is not suitable to display the circuitry connection within the limited space of this article. Table 1 shows the complete pin connections of the product.

Table 1: Connection Pins of Components On Arduino MEGA Board

\begin{tabular}{|l|l|l|}
\hline Components & $\begin{array}{l}\text { Component } \\
\text { pins }\end{array}$ & $\begin{array}{l}\text { Arduino } \\
\text { pins }\end{array}$ \\
\hline \multirow{5}{*}{ Buzzer } & Anode(+) & A15 \\
\cline { 2 - 3 } & Cathode(-) & Gnd \\
\hline \multirow{5}{*}{ 5V } & 5V \\
\cline { 2 - 3 } & 3V & 3V \\
\cline { 2 - 3 } & Gnd & Gnd \\
\cline { 2 - 3 } & LCD_D2 & D3 \\
\cline { 2 - 3 } & LCD_D3 & D4 \\
\cline { 2 - 3 } & LCD_D4 & D5 \\
\cline { 2 - 3 } & LCD_D5 & D6 \\
\cline { 2 - 3 } & LCD_D6 & D7 \\
\cline { 2 - 3 } & LCD_D7 & D8 \\
\cline { 2 - 3 } & LCD_D0 & D9 \\
\hline
\end{tabular}




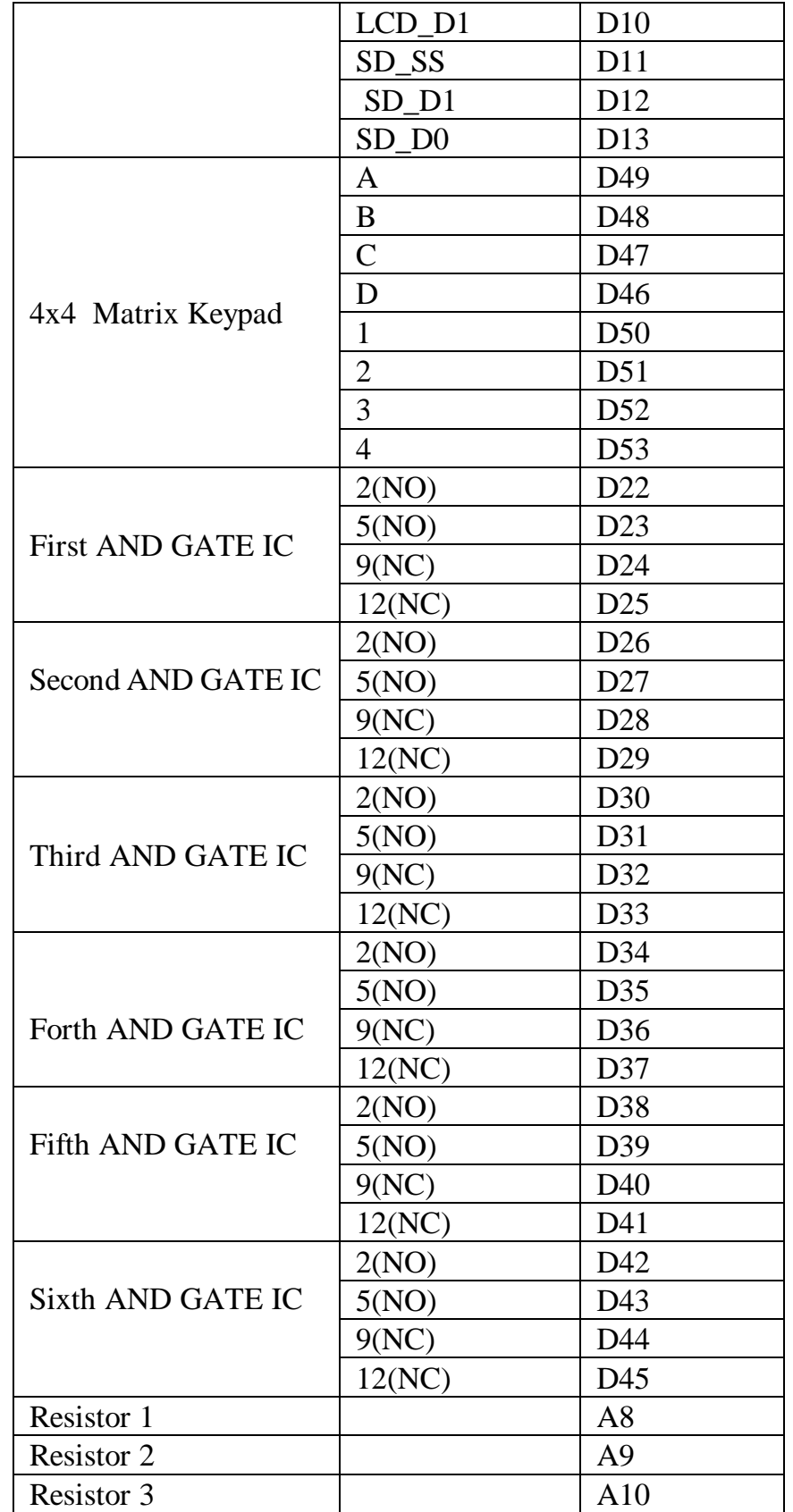

\section{RESULT AND DISCUSSION}

A scenario test is performed to ensure that the PLC EQB user's flow is as expected. Table 2 shows the step-by-step of the flow of the scenario testing for a single question.
Table 2: Scenario of The PLC EQB

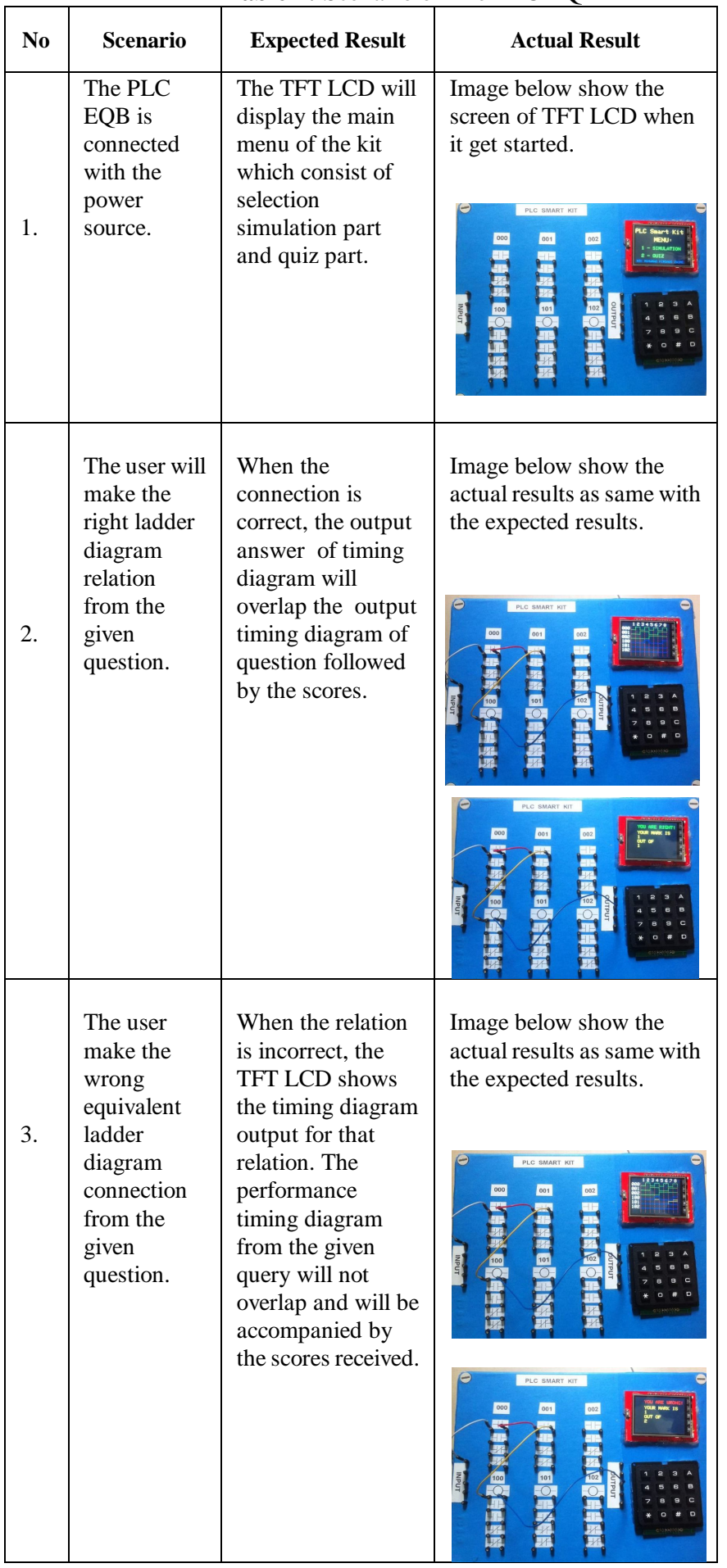

To gauge the functionality of the EQB, a survey consists of 10 questions had been distributed among respondents from the third year Bachelor of Electronic Engineering Technology students of Faculty of Electrical and Electronics Engineering Technology, Universiti Teknikal Malaysia Melaka. Table 3 shows the details of the survey questions asked to the respondents. The questions used 5-scale of Linkert Scale which are: Highly Agreed, Agreed, Neutral, Disagreed, and Highly Disagreed. 
Table 3: Details Of Survey Questions

\begin{tabular}{|l|l|c|}
\hline No & Question & Type \\
\hline 1 & $\begin{array}{l}\text { If it is a PLC trainer kit during the } \\
\text { simulation, it will offer true answers } \\
\text { according to the link. }\end{array}$ & $\begin{array}{c}\text { 5-scale } \\
\text { Linkert } \\
\text { (5SL) }\end{array}$ \\
\hline 2 & $\begin{array}{l}\text { To assess student awareness, the questions } \\
\text { asked by the PLC trainer kit are } \\
\text { appropriate. }\end{array}$ & 5SL \\
\hline 3 & $\begin{array}{l}\text { During class sessions, PLC trainer kits can } \\
\text { be a highly interactive activity. }\end{array}$ & 5SL \\
\hline 4 & $\begin{array}{l}\text { The PLC trainer kit will help students build } \\
\text { their hands-on skills. }\end{array}$ & 5SL \\
\hline 5 & $\begin{array}{l}\text { After answering the full questions in the } \\
\text { PLC trainer pack, students gained a better } \\
\text { understanding. }\end{array}$ & 5SL \\
\hline 6 & $\begin{array}{l}\text { During the laboratory session, the PLC } \\
\text { trainer kit can be used for the Automation } \\
\text { subject. }\end{array}$ & 5SL \\
\hline 7 & $\begin{array}{l}\text { Students tend to study the topic of } \\
\text { automation rather than theoretically by } \\
\text { using the PLC trainer package. }\end{array}$ & 5SL \\
\hline 8 & $\begin{array}{l}\text { This training kit will assist lecturers to } \\
\text { teach ladder diagram to students. }\end{array}$ & 5SL \\
\hline 9 & $\begin{array}{l}\text { Without the guidance of an educator / } \\
\text { teacher, students may operate this } \\
\text { educational kit. }\end{array}$ & 5SL \\
\hline 10 & $\begin{array}{l}\text { Do you think that this PLC Trainer kit can } \\
\text { be commercialised in the industry? }\end{array}$ & 5SL \\
\hline
\end{tabular}

The survey is then distributed to 50 students from Faculty of Electrical \& Electronics Engineering Technology, University Teknikal Malaysia Melaka in order to obtain the feedback. The methodology of conducting the survey is as follows: 1) the kit is being demonstrated (for around 10 minutes) to each of the respondent; 2) respondent is given at least 15 minutes to try out the quiz baord; 3 ) respondent is require to answer the survey. Figure 3 shows the frequency of the feedback for all of the questions.

According to the bar chart shown in Figure 3, base on question 1 survey, 35 repondents indicated agree that this trainer will give true answer during simulation, provided that the connection is correct while 13 respondents strongly agreed. Only 2 respondents were neutral. On the second questions, 31 respondents agree with the questions asked on the trainer whether or not it could help to test students knowledge in PLC. 18 students voted strongly agreed and 1 were neutral in their respond.

On the third questions, 24 respondents were agree that this trainer kit will introduce interactive activity during class session. The other 24 repondents voted strongly agree and only two respondents side as neutral. The fouth survey questions shows that 22 of the respondents voted agree with the suggestion that this kit will help to improve their hands-on skill on PLC. 26 repondents strongly agree with the survey and again only two respondents is neither agree nor disagree with the questions.

As for the fifth questionnaire study, 28 respondents decided that after answering all the questions in this trainer kit, students gained a better understanding. Two respondents voted neutral while the rest said strongly agree. Base on the sixth survey questionaire, 30 respondents voted agree that this trainer can be used during laboratory session for subject Automation. Only one respondents neither agree nor disagree and the rest mentioned strongly agreed.

There were 21 respondents and 23 respondents voted for agree and strongly agree respectively for the questionare number seven. While about six respondents were neutral when compare learning base on this trainer kit versus theoritical learning method. Base on the eighth questionaire, 30 respondents agree that this kit could help lecturer to teach on ladder diagram. While 28 respondents said strongly agree with the statement. Only two respondents voted for neutral.

Referring to the ninth questionaires, there are 29 respondents strongly agree with the suggestion that students could operate this trainer kit without the guidance from the educator or lecturer. While 20 respondents also agree with the statement, however, there one respondents disagree and strongky disagree respectively that students could operate without lecturer guidance. On the final questionaire, 27 respondents strongly agree and 31 respondents voted agree that this trainer kit could be commercialize in the market. Only two respondents was neutral on the last questionaire survey.

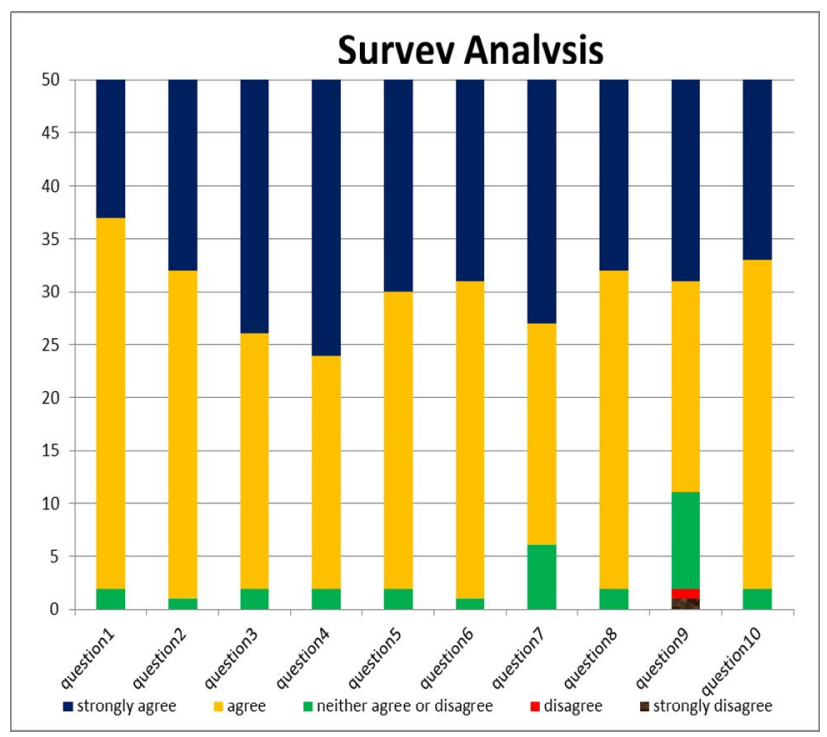

Figure 3: Result from the survey

Starting from Fig. 3, the respondents strongly indicated that the instructional kits are useful for checking student awareness, helping to develop their hands-on abilities, and can be applied to Automation subjects similar to the Ladder Diagram Timing Diagram during the lab session. Overall, respondents decided that they prefer to practise instead of theoretically using the PLC trainer kit, and educators will benefit from using the training kit during the laboratory session. If they have to operate the educational kit without the advice, some respondents disagree. Respondents also agree that in business, this education package can be marketable. 


\section{CONCLUSIONS}

This paper presented the development of the PLC EQB Kit, an electronic training kit that tests the knowledge of students in translating the timing diagram to the PLC Ladder Diagram. Using Scenario testing, the proof of concept functionality is checked when its user acceptance has been verified by a short survey.

\section{ACKNOWLEDGEMENT}

This paper was supported by Faculty of Electrical \& Electronics Engineering Technology, Universiti Teknikal Malaysia Melaka (UTeM) under Centre for Research and Innovation Management (CRIM) Publication Incentives.

\section{REFERENCES}

1. M. R. Yaacob, A. I. M. Diah, A. F. Z. Abidin, K. A. Kadiran, R. F. Mustapa, M. Abdullah, M. I. Ismail, S. N. A. H. Zaiton, e-Flowchart: An Electronic Educational Quiz Board that Test Student Knowledge on C Programming Concept using Flowchart Command, ARPN Journal of Engineering and Applied Sciences, vol. 13, no. 23, pp. 9081-9085, 2018.

2. M. S. Karis, A. F. Z. Abidin, N. Z. Nizam, W. H. Mohd Saad, N. M. Ali, A. Shokri, Laplace Circuit Solver - A Tacticle-based Educational Electronic Board Simulator for Producing Electrical Circuit`s Laplace Transform Equation, International Journal of Recent Technology and Engineering (IJRTE), 2019.

3. M. I. Z. M. Zabidi, L. T. Yung, K. A. Kadiran, A. F. Z. Abidin, M. H. Harun, M. S. Karis, N. M. Ali, Z. M. Yusoff, e-Transform: High School Educational Kit for Learning Mathematical Transformation, Proceeding of Innovative Teaching and Learning Day 2018, 2018.

4. M. H. A. H. A. M. Faseh, F. N. Ismail, M. A. Majid, A. F. Z. Abidin, Z. M. Yusoff, R. Rifin, K. K. Hasan, N. M. Ali, Z. I. Rizman, E-PLC: The Development of a Programmable Logic Controller Trainer that Translates Mnemonic Codes to Hardware Simulation, Journal of Fundamental and Applied Sciences, vol. 10, no. 2S, pp. 499-513, 2018.

5. A. Anuar, A. F. Hussin, M. A. Majid, A. F. Z. Abidin, Z. M. Yusoff, K. K. Hassan, N. M. Ali, M. H. Harun, Z. I. Rizman, E-Tester: The Development of an Electronic Board that Check Commonly Used Arduino-Based Electronic Components and Modules, Journal of Fundamental Applied Science, vol. 10, no. 2S, pp. 514-523, 2018.

6. R. Rifin, T. E. Fang, A. F. Z. Abidin, A. Adam, M. A. Majid, A. Zainuddin, S. H. Mohammad, M.H. Harun, Z. I. Rizman, Examwiz: A Development and Implementation of an Android Based Examination, Journal of Fundamental Applied Science, vol. 10, no. 6S, pp. 965-976, 2018.
7. A. F. Hafizan, A. F. Z. Abidin, N. Z. N. Suhaimi, M. M. Mustam, K. A. Kadiran, S. A. Saleh, W. N. A. Rasid, E-Congkak: The Development of an Electronic Congkak Board Game to Promote Traditional Board Game to Younger Malaysian Generation, $A R P N$ Journal of Engineering and Applied Sciences, vol. 13, no. 24, pp. 9624-9630, 2018.

8. M. A. Hairuddin, N. D. K. Anuar, Z. M. Yusoff, A. F. Z. Abidin, M. T. Nooritawati, Computer Assisted E-Laboratory using LabView and Internet-of-Things Platform as Teaching Aids in the Industrial Instrumentation Course, International Journal of Online Engineering, vol. 14, no. 12, pp. 26-42, 2018.

9. I. A. Rozani, A. F. Z. Abidin, M. S. Karis, M. N. M. Nizam, A. H. Azahar, M. H. Harun, Z. M. Yusoff, K. K. Hassan, B. N. Shah, E-Othello: The Development of an Electronic-Hardware version of Traditional Othello Board Game, ARPN Journal of Engineering and Applied Sciences, 2019.

10. M. A. Husaini, A. F. Z. Abidin, B. N. Shah, M. B. Abdullah, K. A. Kadiran, A. K. Khalid, H. B. A. Kasim, D. C. Lat, R. Razali, N. S. A. Rahman, Rabbit and Carrot Electronic Board Game: The Development of an Educational Kit that Test Student Knowledge in Flowchart Concept, ARPN Journal of Engineering and Applied Sciences, 2019.

11. Heru Supriyono, Rifqi Fauzi Rahmadzani, Muhammad Syahriandi Adhantoro, Developing Computer Application for Interactive Javanese Letters Learning, International Journal of Advanced Trends in Computer Science and Engineering (IJATCSE), Volume 8, No.6, 2019.

12. Rizhal Hendi Ristanto, Mieke Miarsyah, Dewi Robiatun Muharomah, Tri Ayu Astuti, Syarifah Aini, Ary Indaryanti Prihatin, Light-Board: Simple Media to Learn Photosynthesis Concepts, International Journal of Advanced Trends in Computer Science and Engineering (IJATCSE), Volume 9, No.1, 2020.

13. M. I. Z. M. Zabidi, L. T. Yung, A. F. Z. Abidin, K. A. Kadiran, M. Abdullah, M. H. Harun, A. H. Azahar, A Brief Review of Educational Kit Publications from Year 2002 to 2016.," ARPN Journal of Engineering and Applied Sciences, 2019.

14. K. A. Kadiran, A. F. Z. Abidin, M. F. Ishak, M. F. Majidan, R. Rifin, Z. M. Yusoff, M. I. Z. M. Zabidin, E. F. Azmi, A. Samsudin, E-Water Level: Educational Kit for Learning Control System by Using Water Level Application, Proceeding of Innovative Teaching and Learning Day 2018, 2018.

15. M. F. Z. M. Zakaria, S. A. C. Aziz, A. F. Z. Abidin, M. A. Adip, N. Rahim, W. H. W. Hassan, The Development of an Electronic Educational Quiz Board that Test Student Knowledge on Control Principle's Second Order Transient Response by Using DC Motor Speed Control as Application, ARPN Journal of Engineering and Applied Sciences, vol. 13, no. 13, pp.4079-4082, 2018. 
16. Thanh-Nhan Huynh-Ly, Huy-Thap Le, Thai-Nghe Nguyen, Integrating courses' relationship into predicting student performance, International Journal of Advanced Trends in Computer Science and Engineering (IJATCSE), Volume 9, No.4, 2020.

17. Lee, C. K, M. S. Sidhu. Engineering students learning preferences in UNITEN: Comparative study and patterns of learning styles, Journal of Educational Technology \& Society 18.3 (2015): 266-281.

18. J. E. Corter, J. V. Nickerson, S. K. Esche and C. Chassapis, Remote versus hands-on labs: a comparative study, 34th Annual Frontiers in Education, 2004. FIE 2004, Savannah, GA, 2004, pp. F1G-17, doi: 10.1109/FIE.2004.1408586.

19. Carlson, Lawrence E., and Jacquelyn F. Sullivan. Hands-on engineering: learning by doing in the integrated teaching and learning program, International Journal of Engineering Education 15, no. 1 (1999): 20-31.

20. Ferguson, C.W., Yan, Y., Kaul, S., Yanik, P.M. Scholarship Program Initiative via Recruitment, Innovation, and Transformation (SPIRIT): SSTEM Program Initiatives and Early Results, ASEE Annual Conference and Exposition, Conference Proceedings 2018-June, Code 138114. 